\title{
Dopamine Receptor Gene Expression in the Human Medial Temporal Lobe
}

James H. Meador-Woodruff, M.D., David K. Grandy, Ph.D., Hubert H.M. Van Tol, Ph.D., Scott P. Damask, B.S., Karley Y. Little, M.D., Olivier Civelli, Ph.D., and Stanley J. Watson, Jr., Ph.D., M.D.

The distributions of the messenger RNA molecules encoding the five known dopamine receptors have been determined in the medial temporal lobe of postmortem human brain. All five receptor $m R N A$ s are present in temporal lobe structures, although their distributions are heterogeneous. The $D_{1}$-like receptors, $D_{1}$ and $D_{5}$, have strikingly dissimilar distributions. $D_{1}$ receptor $m R N A$ is abundant in temporal neocortex but is rare elsewhere. $D_{5}$ receptor message, however, is seen in the hippocampus, subicular complex, and in temporal cortex. The $D_{2}$-like receptors have similar distributions: $D_{2}, D_{3}$, and $D_{4}$ receptor $m R N A$ s are all identifiable in the hippocampal formation and in the cortical regions of the medial temporal lobe. Distinct patterns of relative regional concentrations for each message are observed, however, suggesting a neuroanatomical substrate for potential differences in dopaminergic regulation within discrete regions of the medial temporal lobe. These results provide a description of the distribution of these receptor mRNAs in normal humans and suggest multiple levels of complexity as well as regulation of the medial temporal lobe dopamine projection. [Neuropsychopharmacology 10:239-248, 1994]
KEY WORDS: Dopamine receptors; Messenger RNA; Hippocampus; Subiculum; Entorhinal; Perirhinal; Cerebral cortex

The medial temporal lobe is a complex structure, comprising the hippocampal formation and several distinct cortical areas. This region of the brain has been implicated in a number of higher functions including memory, stress response, and affective modulation. Further,

From the Mental Health Research Institute (JHM-W, SPD, SJW) and the Department of Psychiatry (JHM-W, SPD, KYL, SJW), University of Michigan, Ann Arbor, Michigan; the Department of Cell Biology and Anatomy and the Vollum Institute for Advanced Biomedical Research, Oregon Health Sciences University, Portland, Oregon (DKG); the Clarke Institute of Psychiatry, University of Toronto, Toronto, Ontario, Canada (HHMVI); the Ann Arbor Veterans Affairs Medical Center, Ann Arbor, Michigan (KYL); and F. Hoffmann La Roche and Co., Ltd., Basel, Switzerland (OC).

Address correspondence to: James H. Meador-Woodruff, M.D., Mental Health Research Institute, Department of Psychiatry, University of Michigan, 205 Zina Pitcher Place, Ann Arbor, Michigan 48109-0720.

Received November 5, 1993; revised January 26, 1994; accepted February 8, 1994. several of these neuroanatomical structures, most notably the hippocampus and the entorhinal cortex, have been implicated in the pathophysiology of schizophrenia by converging lines of evidence including neuropathological and neurochemical data, animal models, and theoretical arguments (Schmajuk 1987; Altshuler et al. 1990; Krieckhaus et al. 1992; Benes et al. 1991; Lipska et al. 1992).

Dopamine has also been consistently implicated in the pathophysiology of schizophrenia, as most antipsychotic medications exert their effects within the dopamine system. The dopaminergic dysfunction is thought to involve the mesocorticolimbic dopamine system, originating in the ventral tegmental area of the midbrain, which projects to a number of more rostral cortical and limbic regions, including the medial temporal lobe structures.

The brain dopamine systems have recently been found to be considerably more complex than previously appreciated. Five dopamine receptor subtypes have now been cloned. These receptors all appear to belong to the superfamily of seven transmembrane domain, 
G-protein coupled receptors. The five dopamine receptors cluster into two distinct groups: a $\mathrm{D}_{1}$-like and a $\mathrm{D}_{2}$ like family. The $\mathrm{D}_{1}$-like dopamine receptors consist of the $D_{1}$ and the $D_{5}$ receptors (Dearry et al. 1990; Zhou et al. 1990; Sunahara et al. 1990; Sunahara et al. 1991; Grandy et al. 1991). These two receptors share similar pharmacological profiles, although they have distinct anatomical distributions (Mansour et al. 1991; MeadorWoodruff et al. 1991, 1992; Fremeau et al. 1991; Mengod et al. 1991; Weiner et al. 1991; Tiberi et al. 1991). The $\mathrm{D}_{2}$-like family of dopamine receptors consists of the $D_{2}, D_{3}$, and $D_{4}$ receptors (Van Tol et al. 1991; Grandy et al. 1989; Giros et al. 1990). These three receptors share a number of common features, including the presence of introns within their coding regions which results in a number of distinct isoforms. These three receptors have high affinities for a number of dopaminergic antagonist drugs with antipsychotic properties, although each receptor subtype has some unique pharmacological features: for example, the $\mathrm{D}_{4}$ receptor has a particularly high affinity for the atypical neuroleptic clozapine (Van Tol et al. 1991). The three $D_{2}$-like receptors differ considerably in terms of their anatomical distributions in the rat brain (Meador-Woodruff et al. 1989; Sokoloff et al. 1992; O'Malley et al. 1992; Najlerahim et al. 1989; Weiner and Brann 1989; Mengod et al. 1989; Bouthenet et al. 1991; Landwehrmeyer et al. 1993): the $D_{2}$ receptor appears to be expressed in most dopaminoceptive regions of the brain, including motor and limbic structures. The $\mathrm{D}_{3}$ and $\mathrm{D}_{4}$ receptors, however, are enriched in limbic system components and are relatively rare in the motor system; this finding may explain the clinical observation of a relative lack of extrapyramidal side effects caused by the atypical antipsychotics. What is particularly interesting about the neurochemical anatomy of the dopamine systems is that the single area of the rat brain that has been demonstrated to express all five of the dopamine receptors is the hippocampal formation.

Both dopamine and the medial temporal lobe have been implicated in the pathophysiology of schizophrenia. Further, it appears that in the rat the dopaminergic innervation of structures within the medial temporal lobe is particularly rich and complex. Because of these considerations, the purpose of the present work was to examine the nature of dopamine receptor gene expression in the medial temporal lobe of normal human brain by determining the location and concentrations of the messenger RNA molecules encoding each of the five dopamine receptors in the various structures in the medial temporal lobe. This descriptive study was designed in anticipation of subsequent experiments involving dopamine receptor gene expression in postmortem brain tissue from schizophrenic subjects.

\section{MATERIALS AND METHODS}

\section{Tissue Samples}

Tissue samples were excised from the brains of three individuals at the time of autopsy, as authorized by the Chief Medical Examiner, State of North Carolina. These individuals were all males (ages 19, 25, and 41 years) who died suddenly (two were homicide victims and sustained gunshot wounds to the chest, and the third suffered from an acute myocardial infarction). All were free of significant chronic medical illness or psychiatric disease and all were screened free of drugs of abuse at the time of death by toxicological analysis. Postmortem interval times were $10,10.5$, and 12 hours.

Blocks of tissue $(1 \mathrm{~cm}$ thick) were removed in a coronal plane from the medial temporal lobe. These blocks originated from the rostral half of the hippocampal formation. These brain samples were immediately frozen on powdered dry ice and stored at $-80^{\circ} \mathrm{C}$ until the time of further processing. Tissue blocks were cryostat-sectioned and $15 \mu \mathrm{m}$ sections were thawmounted onto poly-L-lysine-subbed microscope slides $\left(2 \times 3\right.$ inch). Slides were stored at $-80^{\circ} \mathrm{C}$ until the time of study.

\section{In Situ Hybridization}

In situ hybridization was performed with riboprobes that were generated from constructs of fragments of specific cDNAs encoding each of the human dopamine receptors, which had been subcloned into a member of the pGEM series of vectors. The human $D_{1}$ receptor probe was a 400 base riboprobe corresponding to the region of the human $D_{1}$ receptor spanning transmembrane domains II to $\mathrm{V}$, containing the second intracytosolic loop. The $\mathrm{D}_{2}$ receptor probe was a $446 \mathrm{bp}$ riboprobe directed to the region encoding the third intracytosolic loop and transmembrane domains VI and VII of the human $D_{2}$ receptor, thus equally recognizing both the short and long isoforms of this receptor. Both of these probes have been previously described in more detail (Meador-Woodruff et al. 1993). The $D_{3}$ probe was a $536 \mathrm{bp}$ fragment of the human $\mathrm{D}_{3}$ receptor (bases 727 to 1262) corresponding to transmembrane domains V to VII, including the third cytosolic loop. The $\mathrm{D}_{4}$ receptor probe was a $236 \mathrm{bp}$ portion of the human $\mathrm{D}_{4}$ receptor (bases 1532 to 1767) and directed to the region of human $\mathrm{D}_{4}$ receptor mRNA encoding transmembrane domain IV and the third intracytosolic loop. The $\mathrm{D}_{5}$ riboprobe was a $900 \mathrm{bp}$ fragment directed against the third intracytosolic loop and transmembrane domains VI and VII (bases 900 to 1799).

Sections were removed from frozen storage and im- 
mersed in $4 \%$ formaldehyde for 60 minutes. These fixed sections were then treated for in situ hybridization as previously described (Meador-Woodruff et al. 1991, 1993). Sections were hybridized with [ ${ }^{35} S$ ]-labeled riboprobes (5 to $20 \times 10^{6} \mathrm{dpm} /$ section) in $75 \%$ formamide hybridization buffer and incubated overnight at $55^{\circ} \mathrm{C}$. Following hybridization, sections were treated with RNase A and then progressively more stringent rinses culminating in a 60 minute wash in $0.5 \times$ SSC at $55^{\circ} \mathrm{C}$. The slides were then dehydrated in graded alcohols and apposed to Kodak X-OMAT film for 5 to 40 days.
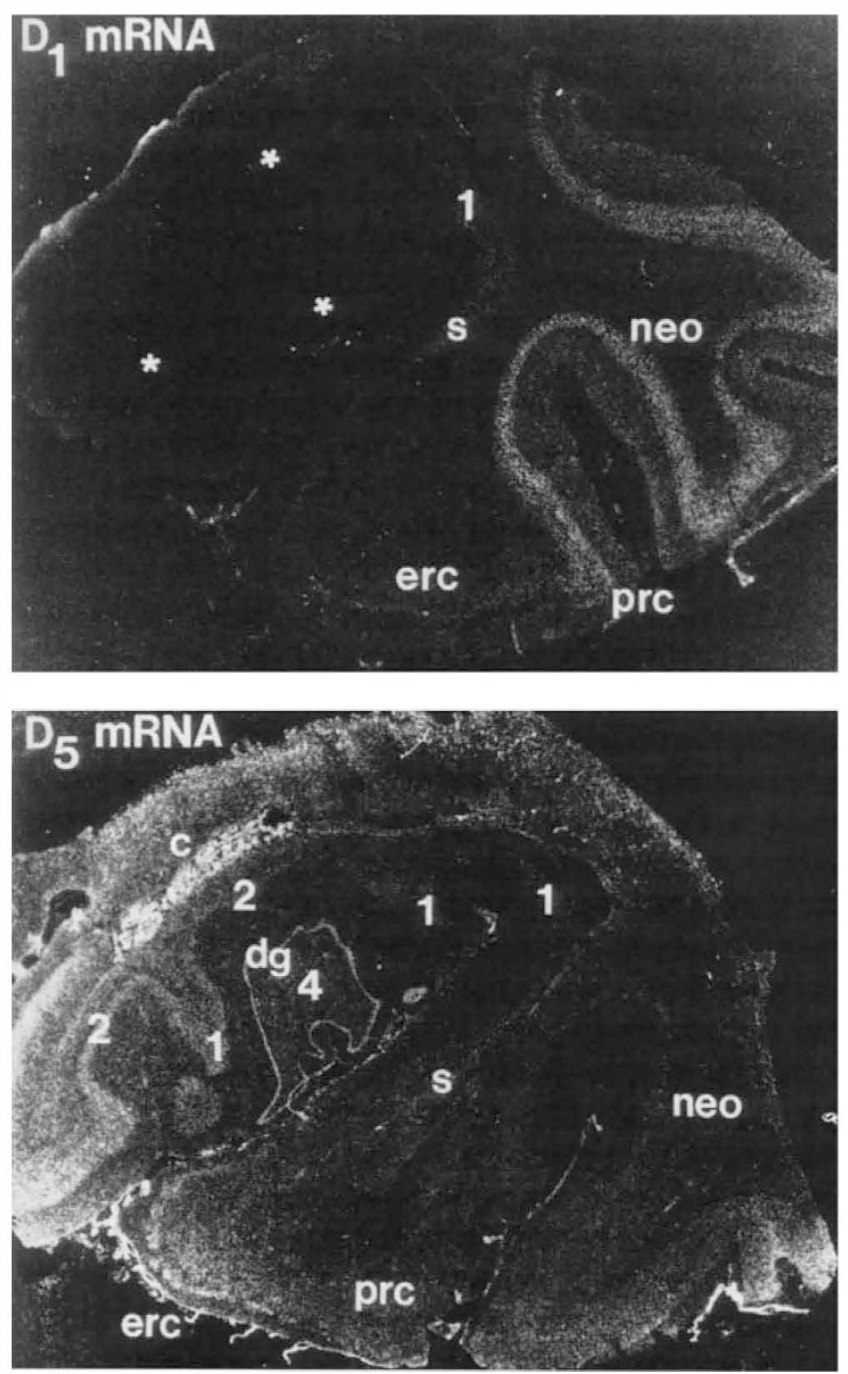

A series of technical control studies was performed to ensure the specificity of each riboprobe used in this study, as we have previously described (Mansour et al. 1990; Meador-Woodruff et al. 1991, 1993). Both "sense"-strand and RNase-pretreated "antisense"labeled sections were run in parallel with "antisense"labeled sections. Under the stringency conditions used in this study, specific hybridization was observed only in the "antisense"-labeled condition, except for faint labeling that was observed in the choroid plexus and the dentate gyrus for some of these probes (Figures 1 and 2).
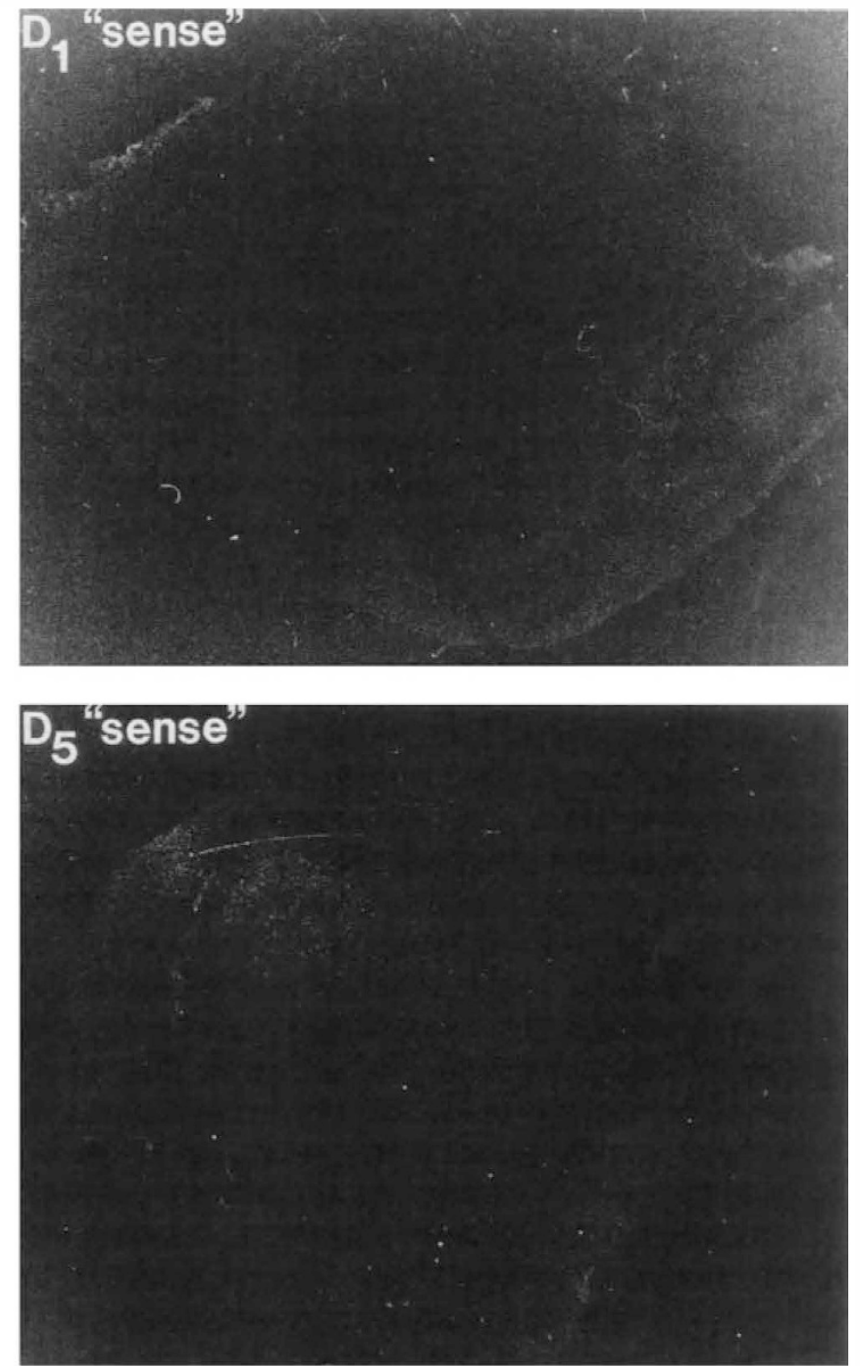

Figure 1. Distributions of the messenger RNAs encoding the $D_{1}$-like dopamine receptors $\left(D_{1}\right.$ and $\left.D_{5}\right)$ in the human medial temporal lobe. Note the striking dissimilarities in the distributions of the mRNAs encoding the $D_{1}$ and $D_{5}$ receptors (left panels). Moderate levels of $\mathrm{D}_{5} \mathrm{mRNA}$ are seen in the granular cell layer of the dentate gyrus with lower levels seen throughout the pyramidal cell layer of CA1-CA4, the subiculum, and associated cortical regions. High levels of $\mathrm{D}_{1}$ receptor mRNA are seen in the neocortex with a small amount in the subiculum and in CA1, and very little in the region of the dentate gyrus and the remaining CA subfields (area delineated with *). The right panels are matched "sense"-strand control images, revealing no significant hybridization. Abbreviations: dg, dentate gyrus; s, subicular complex; erc, entorhinal cortex; prc, perirhinal cortex; neo, neocortex; c, choroid plexus. CA1-4 are abbreviated with numerals (1 to 4). 

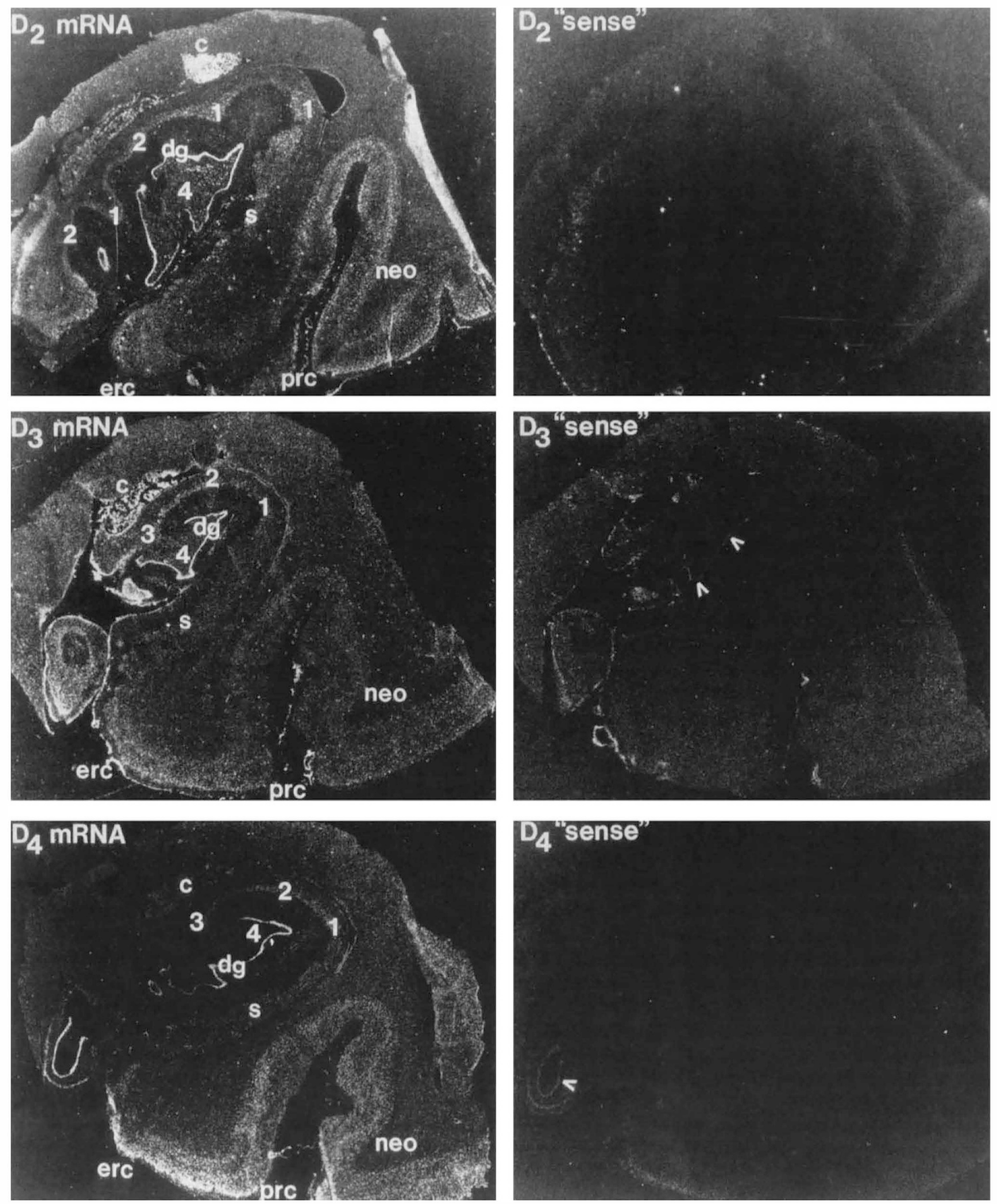

Figure 2. Distributions of the mRNAs encoding the $D_{2}$-like dopamine receptors $\left(D_{2}, D_{3}\right.$, and $\left.D_{4}\right)$ in the human medial temporal lobe. Note the similarities in the distributions of these mRNAs (left panels); for all three, moderate levels of corresponding mRNA are seen in the granular cell layer of the dentate gyrus, with lower levels seen throughout the pyramidal cell layer of CA1-CA4, the subiculum, and associated cortical regions. These distributions are similar to what was observed for $\mathrm{D}_{5} \mathrm{mRNA}$ (Figure 1). The right panels are corresponding "sense"-strand control images revealing no significant hybridization except for faint, nonspecific labeling of the dentate gyrus for $\mathrm{D}_{3}$ and $\mathrm{D}_{4}$ (arrows). Abbreviations are the same as those in Figure 1. 


\section{Data Analysis}

Films were digitized and optical densities in anatomical regions of interest were determined using quantitative densitometry. Regions of interest were identified from Nissl-stained slides that had been used for in situ hybridization. Mean optical density values were obtained for each region studied for each probe from multiple slides per subject. These values were averaged to provide a single value for each region and each probe for each subject. To express relative amounts of each message across all of the regions of interest, mean optical densities for each region were normalized to the mean optical density for the neocortex for each dopamine receptor probe.

\section{RESULTS}

The distributions of the mRNAs encoding the five dopamine receptors are demonstrated in Figures 1 and 2 . $D_{1}$ receptor mRNA was concentrated primarily in deeper layers of the neocortex with moderate levels of expression in the perirhinal cortex, the subiculum, and in the pyramidal cell layer of CA1. Expression of this receptor message in other regions was extremely low; in some sections, faint labeling could be observed, but in others, no appreciable labeling could be discerned. The image in Figure 1 is representative of expression of this mRNA.

$\mathrm{D}_{2}$ receptor mRNA was seen throughout the medial temporal lobe. The granular cell layer of the dentate gyrus exhibited the highest level of labeling. Other regions expressed low to moderate $\mathrm{D}_{2}$ receptor mRNA expression. The pyramidal cell layers of CA1-CA4 all had modest levels of expression, as did the subiculum, including the presubiculum and the parasubiculum. Deep layers of entorhinal and perirhinal cortex had modest levels of expression, and both superficial and deep layers of temporal neocortex expressed this mRNA.

$D_{3}, D_{4}$, and $D_{5}$ receptor messages were noted to have quite similar distributions. Fairly high levels of expression of all were observed in the granular cell layer of the dentate gyrus with modest levels seen in the pyramidal cell layer of CA1-CA4 and somewhat lower levels in the subiculum. Both superficial and deep layers of entorhinal, perirhinal, and neocortical areas were faintly labeled.

Quantitation (as determined by optical density) of the relative abundances of each message in each anatomical subdivision was also performed; these results are summarized in Figure 3. Three general patterns of distribution of dopamine receptor mRNA across each region were observed. The first pattern was a $D_{1-}$ specific distribution, which consisted of highest levels of mRNA expressed in the neocortex, with lowest lev- els in CA2-CA4 and in the presubiculum. The second observed pattern was a distribution unique to $D_{2}$ receptor $\mathrm{mRNA}$, in which all regions were noted to have similar levels of mRNA except the dentate gyrus, where higher levels were seen. The third pattern was seen for the $D_{3}, D_{4}$, and $D_{5}$ receptors. This pattern consisted of relatively higher levels of expression in the dentate gyrus, CA2, and the general area from the presubiculum through the entorhinal cortex. Interestingly, this pattern is generally opposite the $D_{1}$ pattern; areas of relative abundance of $D_{3}, D_{4}$, and $D_{5}$ receptor mRNAs correspond to those areas in which $D_{1}$ receptor message was relatively scarce.

For a variety of technical reasons, it is difficult to accurately compare relative concentrations between each message. Nonetheless, an estimate of relative concentration of each mRNA species in each region was also made by adjusting optical density readings for probe length, number of radioactively labeled bases, exposure time, and rate of radioactive decay. Based on these approximations it appears that $D_{2}, D_{4}$, and $D_{5}$ receptor mRNAs are about equimolar throughout the hippocampus, and $D_{3}$ receptor mRNA is two- to fivefold lower than these three messages. $D_{1}$ receptor mRNA is quite rare, being present in concentrations of five- to 20-fold lower than those of $D_{2}, D_{4}$, and $D_{5}$, and at least two- to three-fold lower than corresponding concentrations of $D_{3}$ receptor mRNA. On the other hand, in the temporal neocortex all five messages appear to be present at comparable levels within a factor of two or three.

\section{DISCUSSION}

These results indicate that the mRNAs encoding the five dopamine receptor messages are differentially expressed throughout the human medial temporal lobe. For the most part, $\mathrm{D}_{2}$ receptor mRNA is expressed at constant levels throughout all of the structures surveyed in this work. $D_{3}, D_{4}$, and $D_{5}$ receptor messages are similarly distributed with relative enrichment in several areas, especially the dentate gyrus, CA2, the parasubiculum, and entorhinal cortex. $\mathrm{D}_{1}$ receptor mRNA, however, is distributed in a unique pattern that is generally opposite the distributions of $D_{3}, D_{4}$, and $D_{5}$. Those areas that are relatively enriched in $D_{3}, D_{4}$, and $D_{5}$ receptor $m R N A s$ are the areas that have a relative scarcity of $D_{1}$ receptor message and vice versa. This complementary distribution has also been reported when binding sites have been studied (Goldman-Rakic et al. 1990; Kohler et al. 1991a) and reveals that certain regions preferentially express certain classes of dopamine receptors. These data suggest region-specific differences in dopaminergic neurotransmission.

Dopamine is well-established as a neurotransmit- 

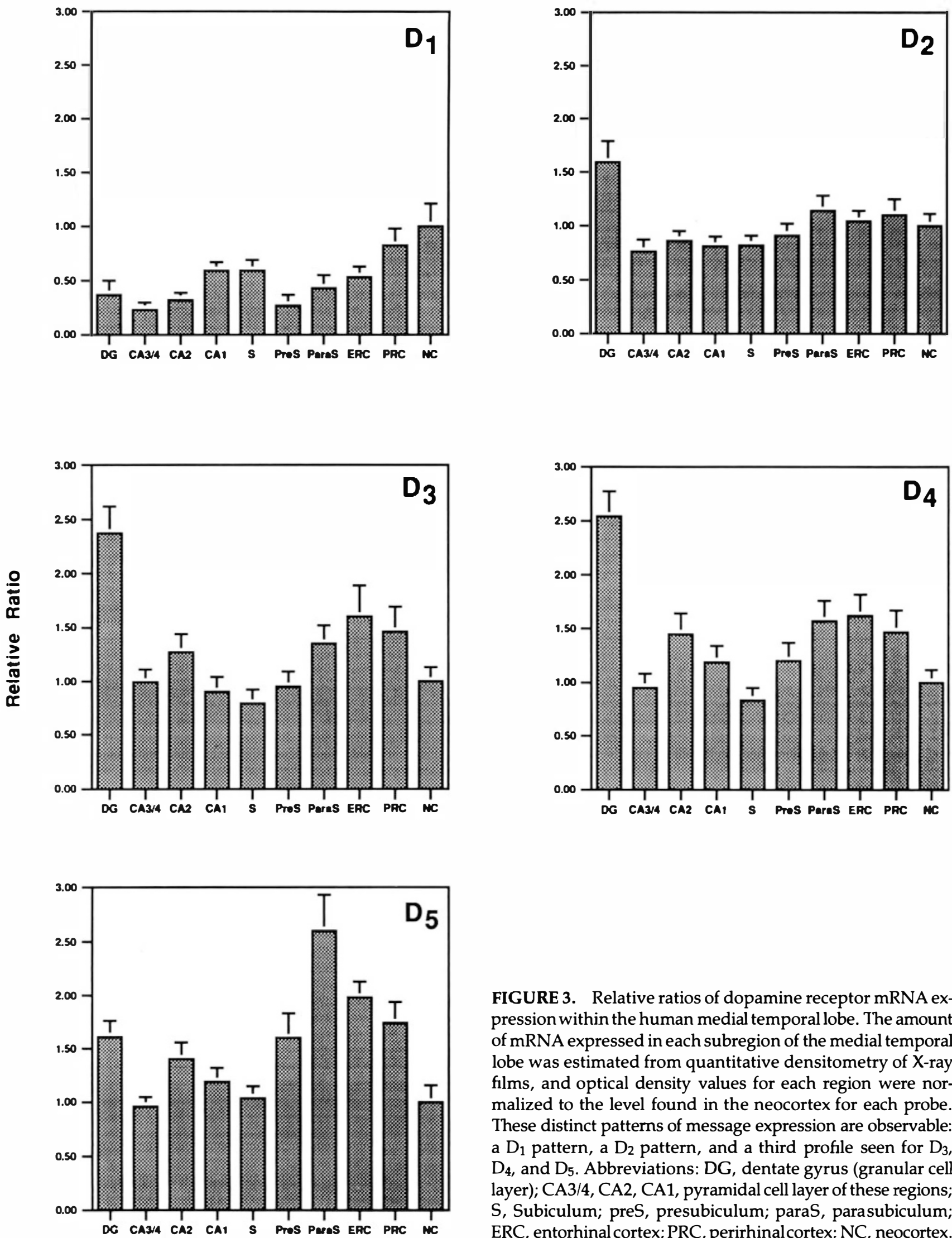

FIGURE 3. Relative ratios of dopamine receptor mRNA expression within the human medial temporal lobe. The amount of mRNA expressed in each subregion of the medial temporal lobe was estimated from quantitative densitometry of $\mathrm{X}$-ray films, and optical density values for each region were normalized to the level found in the neocortex for each probe. These distinct patterns of message expression are observable: a $D_{1}$ pattern, a $D_{2}$ pattern, and a third profile seen for $D_{3}$, $\mathrm{D}_{4}$, and $\mathrm{D}_{5}$. Abbreviations: DG, dentate gyrus (granular cell layer); CA3/4, CA2, CA1, pyramidal cell layer of these regions; $S$, Subiculum; preS, presubiculum; paraS, parasubiculum; ERC, entorhinal cortex; PRC, perirhinal cortex; NC, neocortex. 
ter in the medial temporal lobe, especially in the hippocampus and the entorhinal cortex (Ishikawa et al. 1982). The dopaminergicinnervation of the medial temporal lobe originates in the midbrain, especially from the ventral tegmental area, but there are afferent fibers from the substantia nigra as well (Scatton et al. 1980; Ferraro et al. 1991). Both $D_{1}$ - and $D_{2}$-like receptors appear to be located within the medial temporal lobe (Dewar and Reader 1989; Diop et al. 1988; Bruinink and Bischoff 1986; Bischoff et al. 1980), and both receptor subtypes appear to be functionally coupled to adenylate cyclase (Grilli et al. 1988). Further, both $\mathrm{D}_{1}$ - and $\mathrm{D}_{2^{-}}$ like receptors have been associated with various electrophysiological properties of the hippocampus (Bernardo and Prince 1982; Pockett 1985; Malenka and Nicoll 1986; Gribkoff and Ashe 1984; Berretta et al. 1990; Yanagihashi et al. 1991; Smialowski and Bijak 1987, 1989), including long-term potentiation (Yanagihashi and Ishikawa 1992; Frey et al. 1989, 1990, 1991), and both have been implicated in the mediation of certain animal behaviors (Borker and Mascarenhas 1991; Packard and White 1989).

Anatomical demonstrations of dopaminergic innervation of the medial temporal lobe have also been performed using a variety of techniques (Fallon et al. 1978). Several studies have employed immunohistochemistry for tyrosine hydroxylase $(\mathrm{TH})$ to demonstrate catecholamine-synthesizing axons projecting to the medial temporal lobe. The difficulty with this approach is that dopaminergic as well as adrenergic and noradrenergic fibers contain $\mathrm{TH}$. Several innovative methods have attempted to resolve the adrenergic/noradrenergic from dopaminergic contributions to $\mathrm{TH}$ immunostaining. In one study, Baulac et al. (1986) lesioned the adrenergic/noradrenergic systems in the rat. Following these lesions, all remaining $\mathrm{TH}$ positive fibers should be dopaminergic. What was seen was rich dopaminergic innervation projecting to the entorhinal cortex as well as the subiculum and CA1. In another study, Samson et al. (1990) also stained for dopamine- $\beta$ hydroxylase (DBH), an enzyme specific to noradrenergic and adrenergic cells. By comparing TH-positive and dopamine- $\beta$-hydroxylase-positive fibers, they concluded that there was a rich dopaminergic innervation to the dentate gyrus, CA1, CA3, and the subiculum of the cynomolgus monkey.

The detailed distribution of dopamine receptor binding sites in the medial temporal lobe have been described. These results have tended to be rather discrepant, but both $D_{1}$ and $D_{2}$-like binding have been reported in most structures in this region. In the rat (Kohler et al. 1991a), $D_{1}$-like binding sites (as determined with $\mathrm{SCH} 23982$, potentially labeling both $\mathrm{D}_{1}$ and $\mathrm{D}_{5}$ sites) were found in deeper layers of entorhinal cortex, parasubiculum, and in the CA subfields, par- ticularly in the stratumlacunosum moleculare. Dawson et al. (1986), using a related ligand (SCH 23390, also potentially labeling both $\mathrm{D}_{1}$ and $\mathrm{D}_{5}$ sites), reported a similar distribution of $\mathrm{D}_{1}$-like binding sites, primarily in the molecular layer of the dentate gyrus and in the CA subfields, but also in the subiculum. Kohler et al. (1991a) reported that $D_{2}$-like sites (determined with NCQ 298) were distributed in a complementary pattern to their demonstration of $\mathrm{D}_{1}$-like sites; $\mathrm{D}_{2}$-like binding was reported in more superficial layers of the entorhinal cortex and in the presubiculum but essentially absent from those areas with appreciable $\mathrm{D}_{1}$-like binding. On the other hand, in a study using spiperone to label $D_{2}$-like receptors $\left(D_{2}, D_{3}\right.$, and $D_{4}$ sites), Bruinink and Bischoff (1993) found significant labeling in the subiculum and in CA1 and CA2, and Bouthenet et al. (1987) reported significant $\mathrm{D}_{2}$-like binding (with iodosulpride, primarily labeling $D_{2}$ and $D_{3}$ receptors) in the subiculum and in the stratum lacunosum moleculare of the CA subfields.

Dopamine receptor binding sites have also been demonstrated in the monkey (Kohler et al. 1991b) and human (Kohler et al. 1991b; Joyce et al. 1991) medial temporal lobe. These results have been variable with NCQ 298 binding ( $D_{2}$-like) being found in the presubiculum and entorhinal cortex in both monkey and human, but when these same regions have been studied with epidepride, little binding was found. Epidepride binding was identified in the subiculum, $\mathrm{CA} 3$, and the dentate gyrus. In less comprehensive surveys, however, modest levels of both $\mathrm{D}_{1}$-like (as determined by $\mathrm{SCH} 23390$ ) and $\mathrm{D}_{2}$-like (using CV 205-502) binding have been demonstrated in the dentate gyrus, CA1, and CA 3 of both the rhesus monkey and human (Camps et al.1990; Cortés et al. 1989).

Following the cloning of the five dopamine receptors, a number of studies were published reporting the distribution of the mRNAs encoding these receptors in the rat brain. The determination of the distribution of these mRNAswas particularly important for several reasons. There is currently a lack of specific ligands for most of these receptors, thus the identification of specific mRNAs is the only unambiguous method to resolve all five of the dopamine receptors. Additionally, the distribution of a given mRNA is distinct from the distribution of corresponding receptor binding sites. The mRNA encoding a receptor is seen only in the cell body that is associated with the receptor; the specific binding sites, however, may be distributed on a number of parts of a given cell including the cell body as well as axons and dendrites, which may be quite distant from the soma. Although the determination of both mRNA and binding sites in some ways provide complementary information, the determination of dopamine receptor mRNA distributions allows the identification of 
specific dopaminoceptive cells. The consensus of a number of studies is that the only region that expresses all five of these receptor mRNAs is the hippocampal formation; $D_{2}, D_{3}, D_{4}$, and $D_{5}$ are all expressed throughout the hippocampal formation of the rat, primarily in the pyramidal cell layer of the hippocampus and in the granular cell layer of the dentategyrus (Tiberi et al. 1991; Meador-Woodruff et al. 1989, 1992; Sokoloff et al. 1992; O'Malley et al. 1992; Najlerahim et al. 1989; Weiner and Brann 1989; Mengod et al. 1989; Bouthenet et al. 1991; Landwehrmeyer et al. 1993). $D_{1}$ receptor mRNA was found to be more limited in its distribution, being located predominantly in the ventral portion of the dentate gyrus (Mansour et al. 1991; MeadorWoodruff et al. 1991; Fremeau et al. 1991; Mengod et al. 1991; Weiner et al. 1991).

Perhaps due to the enormity of the task, comprehensive surveys of the distributions of dopamine receptor mRNAs in the human (as well as in monkeys) have been lacking. Because of the potential clinical implications of the dopaminergic regulation of the medial temporal lobe, as well as the codistribution of these five receptor messages in the rat hippocampal formation, we undertook this study to begin to describe the distributions of the five dopamine receptors in the human brain focusing on the temporal lobe structures.

Several features of the present findings are of interest. Similar to results previously reported in the rat brain, all five of the dopamine receptors appear to be expressed in this region of the human brain. Further, the expression of these genes appears somewhat similar in the human to that seen in the rat, especially the minimal distribution of $D_{1}$ receptor mRNA in the hippocampus relative to the mRNAs encoding the other four receptors (Mansour et al. 1991; Meador-Woodruff et al. 1991; Fremeau et al. 1991; Mengod et al. 1991; Weiner et al. 1991). These data are in reasonable agreement, but not complete agreement, with previous binding results. There are a number of possible explanations for such discrepancies. Foremost, the distributions of binding sites and corresponding mRNA for a given receptor do not necessarily overlap, as noted above. In the hippocampus, for example, the cell bodies synthesizing the $D_{2}$ receptor are primarily located in the pyramidal cell layer, whereas the associated binding sites are located in the stratum lacunosum moleculare on terminal processes. The lack of receptor-specific ligands for binding studies may also explain some minor discrepancies, given that most ligands that have been used in past binding studies are now realized to have high affinities for multiple dopamine receptors.

Both the medial temporal lobe and dopaminergic dysfunction have been implicated in the pathophysiology of schizophrenia. These data suggest that the human medial temporal lobe is the recipient of rich and complex dopaminergic innervation. Given that all five of the dopamine receptors are expressed in the human medial temporal lobe, but are differentially distributed, this suggests many possible substrates for subtle levels of dopaminergic regulation (and corresponding possibilities for dysregulation) within this region of the brain. The rather low variances observed for each probe suggest that it may be quite feasible to study the expression of these five receptors within an anatomical context in the brain, especially in psychiatric illnesses such as schizophrenia.

\section{ACKNOWLEDGMENTS}

Dr. Meador-Woodruff is the recipient of a Research Scientist Development Award (MH00818). This work was also supported by a grant from The Stanley Foundation (to JHMW), MH42251 (to SJW), as well as by MH48991, DK47093, and a grant from the American Parkinsons Disease Association (to DKG). The authors appreciate the enthusiastic technical assistance of Jennifer Saul and Carolyn Work, and the advice of Dr. John Butts, Chief Medical Examiner, State of North Carolina.

\section{REFERENCES}

Altshuler LL, Casanova MF, Goldberg TE, Kelinman JE (1990): The hippocampus and parahippocampus in schizophrenic, suicide, and control brains. Arch Gen Psychiatry 47:1029-1034

Baulac M, Verney C, Berger B(1986): Innvervation dopaminergique des regions para-hippocampiques et hippocampiques du rat. Rev Neurol (Paris) 142:895-905

Benes FM, Sorensen I, Bird E (1991): Reduced neuronal size in posterior hippocampus of schizophrenic patients. Schizophr Bull 17:597-608

Bernardo LS, Prince DA (1982): Dopamine action on hippocampal pyramidal cells. J Neurosci 2:415-423

Berretta N, Berton F, Bianchi R, Capogna M, Francesconi W, Brunelli M (1990): Effects of dopamine, $D_{1}$ and $D_{2}$ dopaminergic agonists on the excitability of hippocampal CA1 pyramidal cells in guinea pig. Exp Brain Res 83:124-130

Bischoff S, Bittiger H, Krauss J (1980): In vivo [ $\left.{ }^{3} \mathrm{H}\right]$ spiperone binding to the rat hippocampal formation: Involvement of dopamine receptors. Eur J Pharmacol 68:305-315

Borker AS, Mascarenhas JF (1991): Role of acetylcholine and dopamine in dorsal hippocampus on hoarding behavior in rats. Indian J Physiol Pharmacol 35:71-73

Bouthenet ML, Martes MP, Sales N, Schwartz JC (1987): A detailed mapping of dopamine $\mathrm{D}_{2}$ receptors in rat central nervous system by autoradiography with [ $\left.{ }^{125} \mathrm{I}\right]$ iodosulpride. Neuroscience 20:117-155

Bouthenet M-L, Souil E, Martres M-P, Sokoloff P, Giros B, Sch wartz J-C (1991): Localization of dopamine $D_{3}$ receptor mRNA in the rat brain using in situ hybridization histochemistry: Comparison with dopamine $\mathrm{D}_{2}$ receptor mRNA. Brain Res 564:203-219

Bruinink A, Bischoff S (1986): Detection of dopamine recep- 
tors in homogenates of rat hippocampus and other brain areas. Brain Res 386:78-83

Bruinink A, Bischoff (1993): Dopamine $D_{2}$ receptors are unevenly distributed in the rat hippocampus and are modulated differently than in striatum. Eur J Pharmacol Mol 245:157-164

Camps M, Kelly PH, Palacios JM (1990): Autoradiographic localization of dopamine $D_{1}$ and $D_{2}$ receptors in the brain of several mammalian species. J Neural Transm [Gen Sect] 80:105-127

Cortés R, Gueye B, Pazos A, Probst A, Palacios JM (1989): Dopamine receptors in human brain: Autoradiographic distribution of $D_{1}$ sites. Neuroscience 28:263-273

Dawson TM, Gehlert DR, McCabe RT, Barnett A, Wamsley JK (1986): $D_{1}$ dopamine receptors in the rat brain: a quantitative autoradiographic analysis. J Neurosci 6:2352-2365

Dearry A, Gingrich JA, Fallardeau P, Freameau RT Jr, Bates MD, Caron MG (1990): Molecular cloning and expression of the gene for a human $\mathrm{D}_{1}$ receptor. Nature 347:72-75

Dewar KM, Reader TA (1989): Distribution of dopamine $D_{1}$ and $D_{2}$ receptors in rabbit cortical areas, hippocampus, and neostriatum in relation to dopamine contents. Synapse 4:378-386

Diop L, Gottberg E. Briere R, Grondin L, Reader TA (1988): Distribution of dopamine $\mathrm{D}_{1}$ receptors in rat cortical areas, neostriatum, olfactory bulb and hippocampus in relation to endogenous dopamine contents. Synapse 2:395-405

Fallon JH, Koziell DA, Moore RY (1978): Catecholamine innervation of the basal forebrain. II. Amygdala, suprahinal cortex and entorhinal cortex. J Comp Neurol 180: 509-532

Ferraro G, Vella N, Sardo P, Caravaglios G, Sabatino M, La Grutta V (1991): Dopaminergic control of feline hippocampal epilepsy: A nigro hippocampal pathway. Neurosci Lett 123:41-44

Fremeau RT Jr, Duncan GE, Fornaretto M-G, Dearry A, Gingrich JA, Breese GR, Caron MG (1991): Localization of $\mathrm{D}_{1}$ dopamine receptor $\mathrm{mRNA}$ in brain supports a role in cognitive, affective, and neuroendocrine aspects of dopaminergic neurotransmission. Proc Natl Acad Sci USA 88:3772-3776

Frey U, Hartmann S, Matthies H (1989): Domperidone, an inhibitor of the $\mathrm{D}_{2}$-receptor, blocks a late phase of an electrically induced long-term potentiation in the CA1region in rats. Biochim Biophys Acta 48:473-476

Frey U, Schroeder H, Matthies H (1990): Dopaminergic antagonists prevent long-term maintenance of posttetanic LTP in the CA1 region of rat hippocampal slices. Brain Res 522:69-75

Frey U, Matthies H, Reymann KG, Matthies H (1991): The effect of dopaminergic $D_{1}$ receptor blockade during tetanization on the expression of long-term potentiation in the rat CA1 region in vitro. Neurosci Lett 129:111-114

Giros B, Martres M-P, Sokoloff P, Schwartz J-C (1990): Clonage du gene du recepteur dopaminergique $\mathrm{D}_{3}$ humain et identification de son chromosome. Acad Sci Paris 311:501-508

Goldman-Rakic PS, Lidow MS, Gallager DW (1990): Over- lap of dopaminergic, adrenergic, and serotoninergic receptors and complementarity of their subtypes in primate prefrontal cortex. J Neurosci 10:2125-2138

Grandy DK, Marchionni MA, Makam H, Stofko RE, Alfano $M$, Frothingham L, Fischer JB, Burke-Howie KJ, Bunzow JR, Server AC, Civelli O (1989): Cloning of the cDNA and gene for a human $\mathrm{D}_{2}$ dopamine receptor. Proc Natl Acad Sci USA 86:9762-9766

Grandy DK, Zhang Y, Bouvier C, Zhou Q-Y, Johnson RA, Allen L, Buck K, Bunzow JR, Salon J, Civelli O (1991): Multiple human $\mathrm{D}_{5}$ dopamine receptor genes: A functional receptor and two pseudogenes. Proc Natl Acad Sci USA 88:9175-9179

Gribkoff VK, Ashe JH (1984): Modulation by dopamine of population responses and cell membrane properties of hippocampal CA1 neurons in vitro. Brain Res 292:327-338

Grilli M, Nisoli E, Memo M, Missale C, Spano P (1988): Pharmacological characterization of $\mathrm{D}_{1}$ and $\mathrm{D}_{2}$ dopamine receptors in rat limbocortical areas. II. Dorsal hippocampus. Neurosci Lett 87:253-258

Ishikawa K, Ott T, McGaugh JL (1982): Evidence for dopamine as a transmitter in dorsal hippocampus. Brain Res 232:222-226

Joyce JN, Janowsky A, Neve KA (1991): Characterization and distribution of $\left.{ }^{125} \mathrm{I}\right]$ epidepride binding to dopamine $\mathrm{D}_{2}$ receptors in basal ganglia and cortex of human brain. J Pharmacol Exp Ther 257:1253-1263

Kohler C, Ericson H, Radesater AC (1991a): Different laminar distributions of dopamine $D_{1}$ and $D_{2}$ receptors in the rat hippocampal region. Neurosci Lett 126:107-109

Kohler C, Ericson H, Hogberg T, Halldin C, Chan-Palay V (1991b): Dopamine $D_{2}$ receptors in the rat, monkey and the post-mortem human hippocampus. An autoradiographic study using the novel $\mathrm{D}_{2}$-selective ligand ${ }^{125} \mathrm{l}$ NCQ 298. Neurosci Lett 125:12-14

Krieckhaus EE, Donahoe JW, Morgan MA (1992): Paranoid schizophrenia may be caused by dopamine hyperactivity of CA1 hippocampus. Biol Psychiatry 31:560-570

Landwehrmeyer B, Mengod G, Palacios JM (1993): Differential visualization of dopamine $D_{2}$ and $D_{3}$ receptor sites in rat brain. A comparative study using in situ hybridization histochemistry and ligand binding autoradiography. Eur J Neurosci 5:145-153

Lipska BK, Jaskiw GE, Chrapusta S, Karoum F, Wienberger DR (1992): Ibotenic acid lesion of the ventral hippocampus differentially affects dopamine and its metabolites in the nucleus accumbens and prefrontal cortex in the rat. Brain Res 585:1-6

Malenka RC, Nicoll RA (1986): Dopamine decreases the calcium-activated after hyperpolarization in hippocampal CA1 pyramidal cells. Brain Res 379:210-215

Mansour A, Meador-WoodruffJH, Bunzow JR, CivelliO, Akil $H$, Watson SJ (1990): Localization of dopamine $D_{2}$ receptor mRNA and $D_{1}$ and $D_{2}$ receptor binding in the rat brain and pituitary: An in situ hybridization-receptor autoradiographic analysis. J Neurosci 10:2587-2600

Mansour A, Meador-Woodruff JH, Zhou Q-Y, Civelli O, Akil $H$, Watson SJ (1991): A comparison of $D_{1}$ receptor binding and mRNA in rat brain using receptor autoradiographic and in situ hybridization techniques. Neuroscience 45:359-371 
Meador-WoodruffJH, Mansour A, Bunzow JR, Van Tol HHM, Watson SJ Jr., Civelli O (1989): Distribution of $\mathrm{D}_{2}$ dopamine receptor mRNA in rat brain. Proc Natl Acad Sci USA 86:7625-7628

Meador-Woodruff JH, Mansour A, Healy DJ, Kuehn R, Zhou Q-Y, Bunzow JR, Akil H, Civelli O, Watson SJ Jr (1991): Comparison of the distributions of $\mathrm{D}_{1}$ and $\mathrm{D}_{2}$ dopamine receptor mRNAs in rat brain. Neuropsychopharmacology 5:231-242

Meador-Woodruff JH, Mansour A, Grandy DK, Damask SP, Civelli O, Watson SJ (1992): Distribution of $D_{5}$ dopamine receptor mRNA in rat brain. Neurosci Lett 145:209-212

Meador-Woodruff JH, Little KY, Damask SP, Mansour A, Watson SJ (1993): Effects of cocaine on dopamine receptor gene expression: A study in the postmortem human brain. Biol Psychiatry 34:348-355

Mengod G, Martinez-Mir MI, Vilaró MT, Palacios JM (1989): Localization of the mRNA for dopamine $\mathrm{D}_{2}$ receptor in the rat brian by in situ hybridization histochemistry. Proc Natl Acad Sci USA 86:8560-8564

Mengod G, Vilaró MT, Niznik HB, Sunahara RK, Seeman P, O'Dowd BF, Palacios JM (1991): Visualization of dopamine $D_{1}$ receptor mRNA in human and rat brain. Brain Res Mol Brain Res 10:185-191

Najlerahim A, Barton AJL, Harrison PJ, Heffernan J, Pearson RCA (1989): Messenger RNA encoding the $D_{2}$ dopaminergic receptor detected by in situ hybridization histochemistry in rat brain. FEBS Lett 255:335-339

O'Malley KL, Harmon S, Tang L, Todd RD (1992): The rat dopamine $\mathrm{D}_{4}$ receptor: sequence, gene structure, and demonstration of expression in the cardiovascular system. New Biol 4:137-146

Packard MG, White NM (1989): Memory facilitation produced by dopamine agonists: Role of receptor subtype and mnemonic requirements. Pharmacol Biochem Behav 33:511-518

Pockett S (1985): Dopaminechanges the shape of action potentials in hippocampal pyramidal cells. Brain Res 342: 386-390

Samson Y, Wu JJ, Friedman AH, Davis JN (1990): Catecholaminergic innervation of the hippocampus in the cynomolgus monkey. J Comp Neurol 298:250-263

Scatton B, Simon H, Le Moal M, Bischoff S (1980): Origin of dopaminergic innervation of the rat hippocampal formation. Neurosci Lett 18:125-131

Schmajuk NA (1987): Animal models for schizophrenia: the hippocampally lesioned animal. Schizophr Bull 13: 317-327

Smialowski A, Bijak M (1987): Excitatory and inhibitory action of dopamine on hippocampal neurons in vitro. In- volvement of $D_{2}$ and $D_{1}$ receptors. Neuroscience 23 : 95-101

Smialowski A, Bijak M (1989): Repeated administration of SCH 23390 enhances the SKF 38393-induced inhibition in the rat hippocampus. Neuroscience 28:409-412

Sokoloff P, Giros B, Martres MP, Andrieux M, Besancon R, Pilon C, Bouthenet ML, Souil E, Schwartz JC (1992): Localization and function of the $\mathrm{D}_{3}$ dopamine receptor. Drug Res 42:224-230

Sunahara RK, Niznik HB, Weiner DM, Stormann TM, Brann MR, Kennedy JL, Gelernter JE, Rozmahel R, Yang Y, Israel Y, Seeman P, O'Dowd BF (1990): Human $D_{1}$ receptor encoded by an intronless gene on chromosome 5 . Nature 347:80-83

Sunahara RK, Guan H-C, O'Dowd BF, Seeman P, Laurier LG, Ng G, George SR, Torchia J, Van Tol HHM, Niznik HB (1991): Cloning of the gene for a human dopamine $D_{5}$ receptor with higher affinity for dopamine than $D_{1}$. Nature 350:614-619

Tiberi M, Jarvie KR, Silvia C, Falardeau P, Gingrich JA, Godinot N, Bertrand L, Yang-Feng TL, Fremeau RT Jr, Caron MG (1991): Cloning, molecular characterization, and chromosomal assignment of a gene encoding a second $D_{1}$ dopamine receptor subtype: Differential expression pattern in rat brain compared with the $D_{1 A}$ receptor. Proc Natl Acad Sci USA 88:7491-7495

Van Tol HHM, Bunzow JR, Guan HC, Sunahara RK, Seeman P, Niznik HB, Civelli O (1991): Cloning of the gene for a human dopamine $D_{4}$ receptor with high affinity for the antipsychotic clozapine. Nature 350:610-614

Weiner DM, Brann MR (1989): The distribution of a dopamine $D_{2}$ receptor $m R N A$ in rat brain. FEBS Lett 253:207-213

Weiner DM, Levey AI, Sunahara RK, Nixnik HB, O'Dowd BF, Seeman P, Brann MR (1991): $D_{1}$ and $D_{2}$ dopamine receptor mRNA in rat brain. Proc Natl Acad Sci USA 88:1859-1863

Yanagihashi R, Ishikawa T (1992): Studies on long-term potentiation of the population spike component of hippocampal field potential by the tetanic stimulation of the perforant path rats: Effects of a dopamine agonist. SKF-38393. Brain Res 579:79-86

Yanagihashi R, Yamanouchi K, Ishikawa T (1991): The effects of apomorphine on the hippocampal field potential in freely moving rats: Pharmacological evidence of the involvement of $D_{2}$ receptors. Neuropharmacology 30 : 177-182

Zhou Q-Y, Grandy DK, Thambi L, Kushner JA, Van Tol HHM, Cone R, Pribnow D, Salon J, Bunzow JR, Civelli $O$ (1990): Cloning and expression of human and rat $D_{1}$ dopamine receptors. Nature 347:76-79 